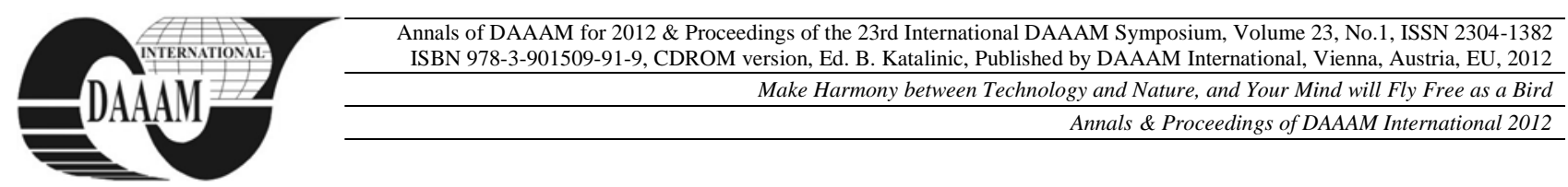

\title{
FINANCIAL RISK MANAGEMENT IN THE CONTEXT OF NEW CHALLENGES TRIGGERED BY THE CRISIS
}

\author{
TUDOSE, M[ihaela] B[rindusa]; CLIPA, F[lavian]; FILIPEANU, D[umitru] \& CLIPA, R[aluca] I[rina]
}

\begin{abstract}
The purpose of this article is to study the manner in which firms promote a risk management adapted to current economic changes, while shifting from an old challenge (the role of indebtedness in maximizing firm value) to a new one: financial fragility and vulnerability to crises. Our premises were: on the one hand, in the context of major imbalances, an increase in debt financing amplifies risks, causing firms to become more financially fragile; on the other hand, internal financing, being more stable and durable, entails minimal risk levels and improves financial vulnerability to crises. The study also emphasises that the current economic and financial system needs to be financed more prudently, in order to sustain a more stable and durable growth rate. Thus, previous coordinates regarding the optimization of firms' financial structure need to be redefined so as to ensure financial sustainability.

Keywords: indebtedness; financial risk; financial fragility; vulnerability; crisis
\end{abstract}

\section{INTRODUCTION}

Unlike the earlier challenges that prompted research in the field (e.g. the capital structure irrelevance or relevance), the present-day challenge consists in the manner in which firms must finance so as to cope with the imbalances (such as crises) that affect the economy. To understand how firms secure the financing of their operations, it is necessary to examine the determining factors of the financing decision. Specialist literature includes a vast body of research on this issue; encapsulating the wide-ranging debates, the determining factors of financial structure have been grouped as follows: a) firm-specific determining factors; b) industryspecific determining factor); c) country-specific determining. Studies that explore the role of variables specific to firms, industries and countries in defining firms' financing policies suggest that the three factor categories influence differently the corporate capital structure. Under normal circumstances, firm-specific factors wield the greatest influence over capital structure. However, in cases when the society is affected by major imbalances (such as crises), the dominance of the influence of specific factors over capital structure changes. As a result, in the context of crises associated with a systemic credit crunch, the impact of macroeconomic factors becomes more extensive, causing an increase in firms' vulnerability and fragility.

The main objective of this article is to examine the incurred risks of firms' financing in a crisis context in order to highlight the link between the various financial structures adopted by firms and their financial vulnerabilities. The operational objectives targeted were: to identify the theoretical foundations of the firm's financing; to highlight the impact of crises on the financial structure (by researching the evolution of the degree of leverage of firms during a series of crises) and to ascertain the types of viable firm financing alternatives.

The methodology underlying the development of this article was hypothetical-deductive. By analysing and summarising the most relevant works in the field, we observed the corporate financing focus shifting from optimality to sustainability; under the banner of these transformations, the optimisation of firms' financial structure must no longer target only the maximisation of shareholder earnings, but should also ensure financial sustainability while minimising risks.

The study is organised as follows: section 2 presents the theoretical foundations of corporate financing; section 3 presents the effects of firms' financing on financial fragility in the context of crises; section 4 provides an overview of the evolution of firms' leverage during various crises and emphasises the lessons that must be learned; the last section summarises results and advances some conclusions.

\section{THEORETICAL FOUNDATION OF FIRMS FINANCING}

F. Modigliani and M. Miller posited that capital structure is optimal at $100 \%$ debt financing (as it minimises the weighted average cost of capital and maximises firm performance and value). The validity of these claims is verified only in the context of preestablished assumptions which characterise an ideal situation. Beyond this shortcoming, the ideas they formulated marked the starting point in laying the foundations of modern finance.

In the 1960s-1970s, research shifted towards studying the way in which firms manage to balance bankruptcy costs with the benefits of tax shields, derived from taking on debt; these works were grouped under the generic headline of "static trade-off theory", whose underlying claim is that firms set a target debt ratio which they attempt to reach. According to the theory, there is a positive relationship between the firm's leverage and performance, also considering the risks incurred.

In the mid-1970s, research turned to agency costs, focusing on two categories of conflicts of interest between managers and shareholders, on the one hand, and between creditors and shareholders, on the other. The research was predicated on the assumption that optimal capital structure represents a compromise between the effects of interest tax shield, financial distress costs and agency costs. "Agency cost theory" posits that it is to be 
expected that increased leverage, in the context of low agency costs, may raise the level of efficiency and thereby contribute to enhancing firm performance; inherently, rising debt will trigger higher risks.

In the first half of the 1980s, the emphasis was mainly placed on information asymmetries among investors and firms, which defined the pecking order theory. The theory argues that there is a hierarchy in the firm's preference for financing its investments, and that compliance with the hierarchy represents the optimal financing strategy. Since issuing new shares would be detrimental to current shareholders, managers prefer to finance investments from internal sources (i.e. retained earnings); if this source proves insufficient, managers will then orient to external sources (first to debt financing and lastly to the issuance of new shares). Thus, according to the pecking order theory, more profitable firms generate higher earnings that can serve for self-financing, enabling them to opt less for debt financing; conversely, less profitable firms do not enjoy the same opportunity, being compelled to take on debt in order to finance their ongoing activity. Consequently, the theory asserts a negative correlation between the debt risks and firm performance.

In the latter half of the 1980s, financial theories explained the structure of firms' financing in relation to factors linked to industrial strategy and corporate organisation. The approach is premised on the influence of debt on the strategic variables (price and quantity) and on the relationship between suppliers and consumers. Compared with the objective of maximising profit posited in specialist literature concerning industrial organisation, these theories recognise that the firm's objective is to maximise shareholders' wealth.

Studies carried out during the 1990 s were marked by the focus on the disjunctive-hypothetical reasoning, as research sought to provide arguments in favour of or against the two theories proposed, i.e. trade-off theory and pecking order theory, respectively. The idea put forward 10 years ago, arguing that "there is no universal theory of the debt-equity choice, and no reason to expect one" [11], reoriented research to the level of empirical analyses.

\section{RECONFIGURATION OF FINANCIAL STRUCTURE: INDEBTEDNESS, RISKS AND FINANCIAL FRAGILITY IN THE CONTEXT OF CRISES}

As shown in the previous section, corporate finance theories did not integrate into their debates the effects of the firm's financing over its financial fragility in the context of crises. On the other hand, this issue received due emphasis in the debates centred on the research of economic cycles (namely, the abrupt booms and busts). Thus, it was acknowledged that, amid major imbalances, the increase of debt financing amplifies risks, causing firms to become more fragile from the financial perspective; conversely, internal financing (using retained earnings), being more stable and durable, entails minimal risk levels and improves financial vulnerability to crises.

The formulation of the hypothesis of financial instability as a theoretical argument of crises was prompted by the following important observations [8]: a) the foundations of the modern capitalist economy are, on the one hand, the investments in financial (capital) assets and, on the other, a sophisticated and complex financial system interconnected with the investment and the real economy processes; b) financial assets, which have the capacity to generate revenue/profit, determine firms to earmark increased funds (including borrowed ones) for investments as they anticipate future earnings; as a result, current demand for investment assets is dependent on the size and intensity of projections of future revenue; compared with this highly elastic demand, the offer of investment assets is inelastic in the short run (as it only changes over the longer term); thus, overoptimistic expectations of future profits (amid the widening gaps between demand and offer) fuel an increase in the prices of investment assets; the rise in asset prices is amplified by financial intermediation (carried out by banks or other financial institutions), which threatens financial stability; c) as a result of the above, there is a general tendency of the financial system to become increasingly leveraged, especially during times of prosperity, which leads to a rise in the degree of vulnerability in the context of potential crises (including in the case of potential systemic credit squeeze).

The study of the effects of debt financing in the context of economic growth and decline precedes the debates laying the foundations of the theories of corporate finance. For instance, Irving Fisher [6] identified two factors playing a dominant role in economic booms and busts: over-indebtedness and deflation. According to him, investments and speculations lead to an over-indebtedness of firms, with serious consequences on the economic cycles; such a financing policy induces abrupt growth and decline, and such oscillations have been viewed as the most important causes of imbalances.

Subsequently, Hyman Minsky [10] expanded on Irving Fisher's debt-deflation theory, examining in closer detail the behaviour of over-indebted firms. According to Minsky, starting from the relationship between the operating income and the payments to service the debt taken on by the debtor, economic entities may fall into one of the following categories [9]: hedge units; speculative units; Ponzi units.

Charles Kindleberger and Robert Aliber, developing the theories of Irving Fisher and Hyman Minsky, argue that speculative tendencies, which lead to over-purchases and over-investment, become irrational, being closely connected to the expansion of credit as a source of overindebtedness [7]. At a certain point, over-indebted investors end up being forced to sell assets to pay their debts. Such asset sales trigger sudden drops in asset prices, inducing a state of panic.

In an environment that favours indebtedness, almost all firms end up being over-indebted and face similar financing problems. Amid a systemic credit crunch, it is rarely possible to finance the firm by contracting new loans. In such a situation, solvent yet illiquid firms may be forced into bankruptcy to the extent that they are temporarily unable to meet their debt commitments [12]. On the other hand, during periods of systemic constraints on liquidity, the odds of financing the cash flow deficit by selling the firm's assets is also limited, because other 
firms behave in the same way to finance their own needs. Even with a very low level of debt, firms cannot avoid crises, because converting assets into liquidity would not be possible. In relatively calm periods, liquidity is less important than solvency, because a solvent firm will be able to secure financing to cover potential liquidity problems. In a crisis environment, liquidity can become more important [3]. Seeking to reinterpret Minsky's financial instability hypothesis, other authors [13, 16] have analysed the net financial flow balances and the liquidity and solvency coefficients of individual units and at aggregate level, classifying firms' financial condition into the following six positions: hyper-hedge units, speculative units, hyper-speculative units, hedge units, highly distressed units, and distressed units [14, 17, 18].

By correlating the grouping of units based on the Minskyan model with the systemic credit squeeze, recent research [12] has highlighted that, although a firm may be viewed as a hedge unit, a systemic credit crunch can induce financial structure fragility (which runs counter to the initial Minskyan claims). This is due to the fact that the crisis can be so severe, systemic and devastating on a global scale, that the firms' prospects of achieving target earnings would suddenly vanish.

The conclusion that emerges is that although it offers a range of advantages, debt triggers serious problems related to financial fragility compared to financing based on retained earnings and own capital. In an environment of uncertainty over projected income, even though firms may have the lowest possible debt ratio, making debt payments at scheduled maturity can pose serious problems. Any economy that relies on uncontrolled leverage is doomed to collapse eventually. Under such circumstances, John K. Galbraith's postulate, proclaimed as early as 1958, still proves its veracity: credit-driven growth is not sustainable.

\section{LESSONS FROM THE PAST: INDEBTEDNESS AND CRISES}

After World War II, the growth of international capital transfers and the liberalisation of monetary policy contributed significantly to increasing debt levels, both in the emerging markets and in the developing nations. The huge foreign capital inflows facilitated over-indebtedness and risk underestimation [2].

Research has shown that, over the course of the history of world economy, the problems triggered by indebtedness have generated more or less far-reaching crises. The examples in this respect are edifying [12]:

a) The crises in certain developing countries (African and Latin-American) at the beginning of the 1980s occurred due to excessive debt; debt (both public and private) rose rapidly and threatened the economic and financial system. As debtors were unable to repay borrowed funds, creditors persuaded governments to take on the private sector debts. As a result, with the expansion of the debt burden, governments - aiming to cope with the debt service - resorted to tax increases and cuts in expenditure on education, health and other social services.

b) The Japanese crisis, beginning in 1980, was linked to indebtedness. In the second half of the 1980s, Japanese firms made major bank-financed investments. This excessive leverage led to huge real estate prices and the formation of a stock bubble. At the beginning of the 1990s, the real estate and stock prices on the Japanese market exploded. Over the span of a few years, the most important Japanese banks and financial institutions became insolvent [7].

c) In the latter half of the 1980, in certain Nordic countries also (Norway, Sweden and Finland) a crisis developed as a consequence of over-indebtedness, with the largest Nordic banks ending up bankrupt.

d) In July 1997, economies in East Asia experienced one of the most serious financial crises in the post-war period. However, prior to the crisis, their models of economic growth had been seen as the most sustainable because the growth in the investment rate relied on external debt, while industrial policy was designed to stimulate investments financed by loans on the international market. Such indebtedness led to speculative bubbles in asset prices, increasing the anticipated returns on investments. Although most of the investments had been speculative, the governments in the region offered implicit guarantees for all kinds of investments, speculative ones included. As a result, after the asset bubble burst, the anticipated returns on investment proved to be an illusion. Because firms had borrowed in particular from banks to finance their investments, and banks, in turn, financed the loans by borrowing US dollars on the international capital markets, a domino effect was created which led to financial panic. When debtors were unable to meet their loan repayments, banks were in turn incapable to make payments on the loans they had taken from international creditors.

e) In the second half of the 1990s, in the United States, corporations in the information technology industry believed that opportunities for immense profits could be sustained through new massive borrowing. The outstanding performance of the real economy fuelled the rise in stock prices, which in turn led to the increase in investment expenses and the rising US growth rate. Nevertheless, the stock price increase halted after a short period, entering an opposite phase, with US stock exchanges losing approximately $40 \%$ of the value over three years [7]. At the turn of the millennium, corporations in the residential and commercial building sector experienced vast credit-driven growth. On the corporate level, financing based on issuing stock lost ground to debt-financing, the period of sustained growth ending disastrously.

f) Since the beginning of 2007, news about asset quality deterioration has hit the markets repeatedly. Simultaneously, there has been a substantial increase in liquidity risk [1]. The extent of the effects of the crisis on the different countries has varied according the vulnerabilities of each individual economy and their exposure to toxic assets. Although the 2008 financial crisis and associated recession have led to serious difficulties, some authors [4] consider that it provided "an opportunity to learn more about the impact of financial constraints on corporate policies".

In light of the above, our view is that the following lessons need to be learned: a) expansion was frequently 
associated with debts, which increased the debtors' vulnerability to shocks [15]; b) the economic, social and cultural structure can shape the degree of indebtedness [19]; c) firms that relied on the debt-financing method, on the one hand, were "rewarded" by the capital markets, while on the other were hit head-on by the crisis [5]; d) innovation in the field of financial debt instruments facilitated the withholding of risks; e) debt is selfreinforcing; to understand the appetite for indebtedness, it is necessary to resort not only to mathematics, statistics and econometrics, but also to anthropology, sociology and psychology in order to explore social behaviours and relations among human beings [12].

\section{CONCLUSIONS}

Amid the transformations that have marked the economic and social life, we are witnessing a reorientation of the research on corporate financing towards the study of the impact of debt financing on financial vulnerability. The old challenge (the ratio of debt in the firm's overall financing) has been abandoned in favour of a new challenge: financial fragility and vulnerability to crises.

The problems related to the way in which firms must finance their operations remain current and acute. This is due to the fact that indebtedness generates financial fragility, while the latter amplifies firms' vulnerability during crisis periods; if a fundamental change does not occur in financing behaviours (in terms of a reduction of debt dependence), the vulnerability of the financial system to crises will be heightened. The basic solution to stabilise the economy is to change firms' financing focus (by reconsidering risks). The present economic and financial system needs a more prudent financing approach, that should support a more stable and sustainable growth rate; this goal becomes achievable only in the context of the redefinition of firms' financing policies, which must be predominantly focused on the use of their own internal and external funds. Moreover, we consider that it is vital to redefine the theoretical foundations of firms' financing in order to achieve compatibility with the phases of the economic cycle.

The final conclusion drawn is that the objective of maximising the positive effects of indebtedness must be abandoned in favour of more prudent financing that should support growth, albeit more moderate, yet also more stable and durable.

Considering that research in the field has expanded considerably over the years, we would like to note that, for the purposes of this study, we aimed to provide a selection of the most relevant research; hence, we acknowledge that the study makes no claim to being exhaustive. Furthermore, we recognise that, due to the rather sterile overview of financial theories (focusing mainly on the main stages of evolution), we may attract blame for inadequate scientific grounding; the real reason is different however - i.e. lack of space. Beyond these limitations, we consider that the stated opinions remain relevant. The paper serves as a starting point for conducting future, more extensive research within the framework of the programme Post-Doctoral Studies in Economics: training program for elite researchers.

\section{ACKNOWLEDGEMENT}

This work was supported by the project "PostDoctoral Studies in Economics: training program for elite researchers - SPODE" co-funded from the European Social Fund through the Development of Human Resources Operational Programme 2007-2013, contract no. POSDRU/89/1.5/S/61755.

\section{REFERENCES}

[1] Acharya, V.; Viswanathan, S. (2011). Leverage, Moral Hazard, and Liquidity, The Journal of Finance, Vol. 66, No. 1 (February 2011), 99-138, ISSN 1540-6261

[2] Bergsten, C. F. (2009). The Dollar and the Deficits: How Washington Can Prevent the Next Crisis. Foreign Affairs, Vol. 88, No. 6, (November / December 2009), 20-38, ISSN 0015-7120

[3] Bernanke, B.; Campbell, J.; Friedman, B. \& Summers, L. (1988). Is There a Corporate Debt Crisis? Brookings Papers on Economic Activity, Vol. 19, No. 1, 83-134, ISSN 0007-2303

[4] Campello, M.; Graham, J. \& Harvey C. (2010). The real effects of financial constraints: Evidence from a financial crisis, Journal of Financial Economics, Vol. 97, No. 3, 470-487, ISSN 0304-405X

[5] Felton, A. \& Reinhart, C. (2008). The First Global Financial Crisisof the 21st Century. Centre for Economic Policy Research, ISBN 978-0-9557009-9-6, London

[6] Fisher, I. (1933). The Debt-Deflation Theory of Great Depressions. Econometrica, Vol. 1, No. 4, 337-357, ISSN 00129682

[7] Kindleberger, C. \& Aliber, R. (2005). Manias, Panics, and Crashes, A History of Financial Crise, Fifth Edition. John Wiley \& Sons Inc: Hoboken, ISBN-10: 0471467146; ISBN-13:9780471467144, New Jersey

[8] Iancu, A. (2010). Sinteză privind modelarea fragilităţii sistemului financiar [Overview of modeling financial system fragility]. Romanian Society for Economic Science, Review OEconomica, Vol. 3 (September/2010) 161-168, , ISSN 1220-0476

[9] Minsky, H. (1986). Stabilizing an Unstable Economy, Yale University Press, ISBN 0300040008; 9780300040005, London

[10] Minsky, H. (1992). The Financial Instability Hypothesis, The Jerome Levy Economics Institute of Bard College, Working Papers No, 74, London

[11] Myers, S. (2001). Capital structure, Journal of Economic Perspectives, Vol. 15, 81-102, ISBN 1450-2275

[12] Sen, A. (2010). A without Debt and Strong Financial Structure. Internetional Research Journal of Finance and Economics, Issue 59 (December 2010), 77-85, ISSN 1450-2887

[13] Sordi S. \& Vercelli, A. (2003). Financial Fragility and Economic Fluctuations: Numerical Simulations and Policy Implications, Universita degli Studi di Siena, Working Paper, no. 407, Siena

[14] Sordi S. \& Vercelli, A. (2006). Financial Fragility and Economic Fluctuations. Journal of Economic Behavior Organization, Vol. 61, No. 4, 543-561, ISSN 0167-2681

[15] Soros, G. (2008). The New Paradigm for Financial Markets, The Credit Crisis of 2008 and What it Means. PublicAffairs, ISBN 9781891620270, New York

[16] Vercelli, A. (1999), Financial Fragility and Cyclical Fluctuations, Universita degli Studi di Siena, Dipartimento di Economia Politica, no. 253, Siena, Italy

[17] Vercelli, A. (2000). Structural Financial Instability and Cyclical Fluctuation. Structural Change and Economic Dynamics, Vol. 11, No. 1-2 (july 2000), 139-156, ISSN 0954-349X

[18] Vercelli, A. (2009). A Perspective on Minsky Moments: The Care of the Financial Instability Hypothesis in Light of the Subprime Crises, The Levy Economics Institute of Bard College, New York

[19] Woods, T. (2009). Meltdown, A Free-Market Look at Why the Stock Market Collapsed, The Economy Tanked, and Government Bailouts Will Make Things Worse. JR. Regnery Publishing, INC. An Eagle Publishing Company, Washington, DC 